\title{
Coronilla varia L. (Fabaceae): AN INVADER OF A COASTAL BARRIER BEACH IN NOVA SCOTIA, CANADA
}

\author{
ANDREA FLYNN, ANTHONY G. MILLER and \\ DAVID J. GARBARY* \\ Department of Biology, St. Francis Xavier University, \\ Antigonish, NS B2G 2W5 Canada
}

\begin{abstract}
Coronilla varia L. (crown vetch) is described as an invasive plant on a coastal sand dune system (Mahoneys Beach) in Nova Scotia facing the southern Gulf of St. Lawrence. This is the first time that $C$. varia has been shown as invasive in Atlantic Canada, and the first time it has been characterized as invasive on coastal sand dunes. Accordingly, colonies of C. varia forming more than $90 \%$ of the plant cover occupy $8 \%$ of the total dune system and account for $32 \%$ of the area in the vegetation zone where $C$. varia has become abundant. C. varia can achieve high percentage cover, with all of the major dune plants, i.e., Ammophila breviligulata, Lathyrus japonicus,Toxicodendron radicans and Myricapensylvanica. Where C.varia achieves maximum abundance (i.e., $>80 \%$ cover and ca. 200 shoots $\mathrm{m}^{2}$ ), it has seemingly replaced A. breviligulata and L.japonicus. We do not know when $C$. varia first colonized Mahoneys Beach, but conspicuous colonies were recorded there by 2005 , and a colony was found on the adjacent dune system (Dunns Beach) for the first time in 2010.

Key Words: Coronilla varia, crown vetch, Fabaceae, invasive species, Nova Scotia, sand dunes
\end{abstract}

\section{INTRODUCTION}

Many recent studies have focused on the substantial threat that invasive alien plants pose to global biodiversity (e.g., Callaway \& Aschehoug 2000, Lake \& Leishman 2004, Pyšek et al. 2004, McClay \& Faechner 2008, Rejmanek 2011). In Nova Scotia, roughly one third of the terrestrial vascular plants are alien species, most of these are found in highly disturbed sites, but only a handful may be considered invasive,i.e., cause significant displacement of native species in natural communities. A recent review by Hill and Blaney (2009) contained 
lists of both herbaceous and woody alien plants in Nova Scotia, and discussed some species that were likely to become significant threats (i.e., invasive) in native plant communities. Our interest here is the coastal sand dune ecosystem, which is under threat from anthropogenically derived disturbances and from sea-level rise (Beveridge 2012). Among these disturbances is the potential impact of invasive species. One woody plant suggested by Hill \& Blaney (2009) as a potential invasive alien on coastal sand dunes was Rosa rugosa Thunb. Hill et al. (2010) later demonstrated its invasive properties on a series of sand dune systems on the north shore of mainland Nova Scotia and the west coast of Cape Breton Island. Here we provide the results of an investigation of Coronilla varia $\mathrm{L}$. (crown vetch), on a coastal sand dune. Whereas C. varia establishes well in sandy soils (Gucker 2009), we found no account regarding its occurrence on sand dunes, and we describe it as an invasive species in this habitat for the first time. While Hill and Blaney (2009) did not consider C. varia as a potential invasive plant in Nova Scotia, it has become invasive elsewhere in North America in a wide variety of plant communities including roadsides, open fields, waste areas and gravel bars along streams (Harper-Lore 1996, Tu 2003, Symstad, 2004, Gucker, 2009, Losure et al. 2009).

Coronilla varia [also known as Sercurigera varia (L.) Lassen] is native to the Mediterranean region of Europe, southwest Asia, and northern Africa (Roland 1998), suggesting that it is adapted to arid environments such as the coastal sand dunes that are the focus here. The species was first introduced to North America in the $19^{\text {th }}$ century and has subsequently spread throughout the continental United States (except Alaska and North Dakota) and all Canadian provinces (Thompson 1997, Gucker 2009, USDA 2009). Its main use in Nova Scotia has been for roadside erosion control (Roland \& Smith 1969, Hill \& Blaney 2009), and, like other Fabaceae, it is a nitrogen fixer (Cardina \& Hartwig 1988, Madigan et al. 2010). The species is now classified as an invasive alien species in the USA (Harper-Lore 1996). However, Roland \& Smith (1969) considered C. varia as "doubtfully hardy" in Nova Scotia, and it has only been classified as alien in Nova Scotia, not invasive (NatureServe 2011). Here we describe the ecology and natural history of $C$. varia on Mahoneys Beach, a coastal sand dune on the north shore of Nova Scotia facing the southern Gulf of St. Lawrence. While we do not know when $C$. varia colonized Mahoneys Beach, it was not recorded here or on any of the 45 Nova Scotian sand 
beach systems $>1 \mathrm{~km}$ long studied by Hales (1992), or on any of the 11 beaches surveyed on the west coast of Cape Breton Island by Beveridge (2012). C. varia was recorded by one of us (AGM, unpublished field notes) on Mahoneys Beach from 2005. By 2010 it had become abundant and we initiated the current study.

\section{MATERIALS AND METHODS}

This study took place on Mahoneys Beach (now Mahoneys Island), an extensive sand dune system in St. Georges Bay, along the extreme southern portion of the Gulf of St. Lawrence of Nova Scotia (Fig 1).

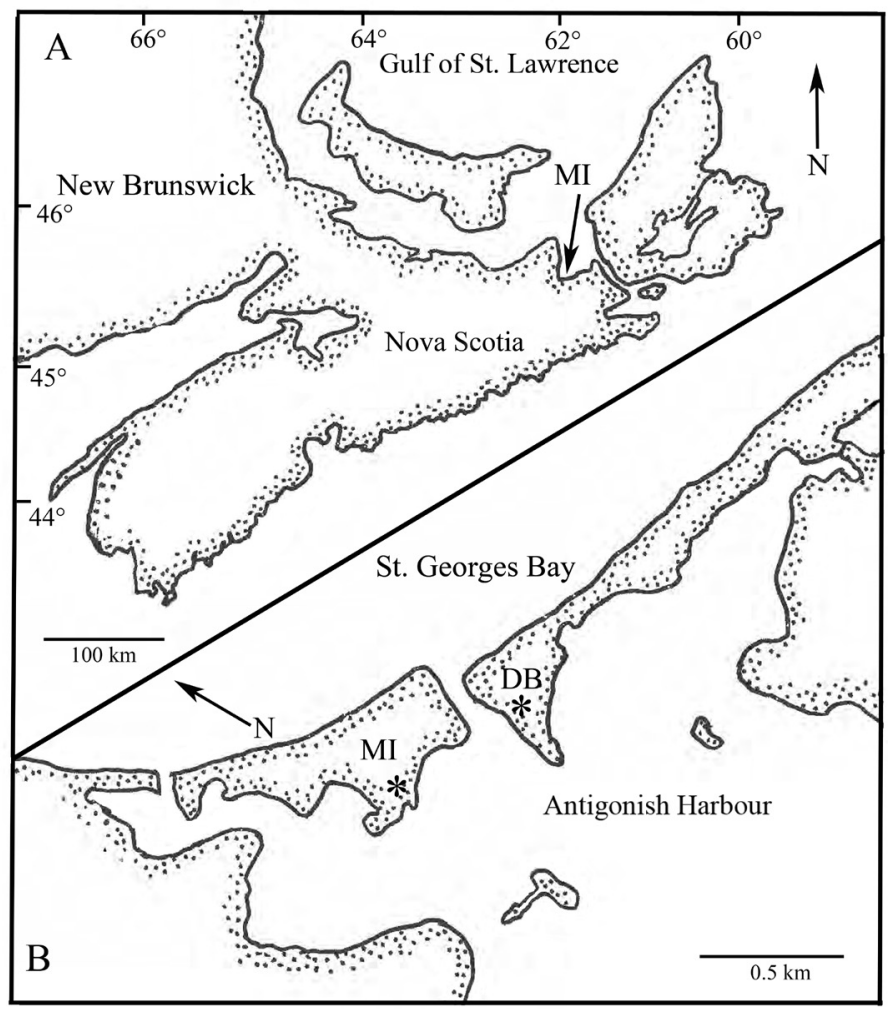

Fig 1 Map of Nova Scotia (A) indicating general location of Mahoneys Island (MI, arrow), and (B) enlargement of barrier beach system for Antigonish Harbour, showing Mahoneys Island (MI) and Dunns Beach (DB). Asterisks in B indicate outlier populations of Coronilla varia. 
The sand dune is a $1.2 \mathrm{~km}$ long island, formed when it separated from the original $1.6 \mathrm{~km}$ spit on December 26, 2004 during a storm. Currently (2013), the island is relatively undisturbed by human activity and it has been a successful nesting site for the regionally rare shorebird Charadrius melodus (Ord) (i.e., Piping Plover). There is severe scarping visible on the seaward side of the island and the dune is retreating by an average of $1.2 \mathrm{~m} \mathrm{y}^{-1}$, with the western end recently retreating by over $5 \mathrm{~m} \mathrm{y}^{-1}$ (Garbary and Miller, unpublished observations). In addition to the impact of sea level rise and regional subsidence, armouring of a headland adjacent to the beach is starving the shore of sediment (Utting and Gallacher 2009).

A walking survey in the late summer of 2011 (September 1) was performed to locate all dense colonies of Coronilla varia on the island. Colonies were measured using a transect line to obtain dimensions for area calculation, and coordinates of each colony were recorded using a Garmin eTrex (Olathe, Kansas) GPS unit. Colonies were considered dense when cover of C. varia was at least $80 \%$. In 2010, C. varia was first observed on Dunns Beach and a similar colony survey was conducted there in September 2012.

Irradiance was determined inside a dense stand of $C$. varia and on adjacent non-vegetated sand, using a HOBO Pendant Temperature/ Light Data Logger (UA-002-XX, Onset Computer Corporation, Pocasset, MA). While the HOBO records light in 'lumens', these data were converted to photosynthetically active radiation (PAR) based on the proportion of the overall spectrum between $400 \mathrm{~nm}$ and 700 $\mathrm{nm}$ sensed by the HOBO. The HOBOs were suspended $10 \mathrm{~cm}$ above ground level and data were collected from July 21 to August 31,2011, at 10 min intervals. A LI-COR light meter (LI-250, Lincoln, NE) with a cosine corrected detector was used to determine photosynthetic photon flux density $\left(\mu \mathrm{mol} \mathrm{m} \mathrm{mec}^{-1}\right)$ at ground level within quadrats $(\mathrm{n}=5)$ where either $C$. varia or its primary associated species, i.e.,

Table 1 Ground level irradiance underneath five species following removal of the primary competitor within each quadrat $(n=5)$.

\begin{tabular}{lc}
\hline Species & $\begin{array}{c}\text { Irradiance } \\
\left(\boldsymbol{\mu} \text { mol } \mathbf{~ p h o t o n s ~} \mathbf{~}^{-2} \mathbf{s e c}^{-1}\right)\end{array}$ \\
\hline Coronilla varia & $565 \pm 69$ \\
Ammophila breviligulata & $561 \pm 109$ \\
Lathyrus maritimus & $432 \pm 136$ \\
Toxicodendron radicans & $419 \pm 87$ \\
Myrica pensylvanica & $217 \pm 88$ \\
\hline
\end{tabular}


Ammophila breviligulata Fern. (beach grass), Lathyrus maritimus (L.) Bigelow (beach pea), Myrica pensylvanica Mirbel (bayberry) and Toxicodendron radicans (L.) Kuntz (poison ivy), had been removed. Data were collected on a day with full sun between 10 am and $2 \mathrm{pm}$. The resulting data (Table 1) were used to infer whether or not light limitation has a role in competitive interactions between $C$. varia and the other species.

Soil pits were dug to $1.0 \mathrm{~m}$ depth within pure stands of each of the dune species, and the depth of root penetration into the sand dune by the various species was observed. Individual shoots were removed with intact roots and rhizomes for photography. Accordingly, differences in zonation would permit inferences regarding below-ground competition.

In the same year (2011) that we mapped colony distribution of Coronilla varia, we determined cover and biomass values in a series of 24 plots where $C$. varia was associated with one of four abundant native plants on Mahoneys Beach, i.e., Ammophila breviligulata, Lathyrus maritimus, Toxicodendron radicans, and Myrica pensylvanica. In early June 2011, for each of the species associations, six experimental plots (replicates) were established (each $1 \times 3 \mathrm{~m}$ ) with three subplots (each $1 \times 1 \mathrm{~m}$ ), and percent cover of the major species was estimated visually in each subplot. In subplot $1, C$. varia was removed by clipping at ground level, in subplot 2 (control) no harvesting occurred, and in subplot 3, the other species were harvested by clipping at ground level. For each subplot the percent cover of the major species were determined in early June, 2011. In late July the two harvested subplots were again evaluated for cover and biomass, and the control subplots were not harvested. These plots were established to experimentally evaluate competitive interactions between $C$. varia and each of the other species. Thus, we evaluated the following pairs of questions for each species combination: 1 ) when $C$. varia is removed, does Species 2 increase in cover and biomass relative to control plots, and 2) when Species 2 is removed, does $C$. varia increase in cover and biomass relative to control plots. These plots were to be re-evaluated in 2012; however, beach erosion in the winter of 2012, and overwash of the primary portion of the beach had removed most of the plots. For each species combination in the experiment, the Wilcoxon paired sample test (Zar 1999) was conducted in which the final values for cover and biomass in 2011 were evaluated against the values in the control subplots where no initial harvest was done. 


\section{RESULTS}

Field surveys revealed that colonies of Coronilla varia were abundant and easy to locate on Mahoneys Beach (Figs 2, 3, 4). The colonies were considered dominant (containing almost exclusively $C$. varia plants), when cover of $C$. varia was at least $80 \%$. Small $C$. varia plants were also observed colonizing open sand, sometimes alongside native species, such as Lathyrus maritimus. The total area of Mahoneys Beach (island portion) in 2011 was estimated to be $342,144 \mathrm{~m}^{2}$. Of the total area of the island, the area of the zone inhabited by $C$. varia was $93,312 \mathrm{~m}^{2}$. Within the zone inhabited by C. varia, the total area of all the colonies of $C$. varia was $29,985 \mathrm{~m}^{2}$. Therefore, dense colonies of $C$. varia took up $32 \%$ of the zone that was inhabited by C. varia, and $9 \%$ of the entire island. In addition, it occurred with other species where it had lower cover.

There were 125 dense colonies present on Mahoneys Beach on the dune proper (Fig 2). In addition, a small population was found amongst populations of Rosa virginiana Mill. adjacent to a small salt marsh and grove of Populus tremuloides Michx. on the extreme landward side of the dune system. The average area of the Coronilla varia colonies was $238 \pm 578 \mathrm{~m}^{2}$ (mean \pm s.d.). The large standard deviation resulted from a highly skewed size distribution (Fig 5) in which 88 out of 125 colonies were between 0 and $50 \mathrm{~m}^{2}$, and 5 colonies were more than $2,000 \mathrm{~m}^{2}$. There was also one very large, continuous colony of $C$. varia in the middle of the island that was approximately $330 \mathrm{~m}$ long and had an area of nearly $9,100 \mathrm{~m}^{2}$. This very large colony was flanked on the northwest and southeast ends by many smaller colonies. The southeast end of Mahoneys Island had more small clumps than the northwest end. On the southwest end, the spaces between colonies with native plant species also contained $C$. varia, but the latter tended to have lower cover values (25-75\%). Therefore, $C$. varia had spread over almost the entire southeast end of the island. If cover values lower than $80 \%$ had been used to define a colony, then the entire southeast end would have been considered a single colony. These areas of lower cover value also occurred elsewhere. There were large areas on the northwest end of Mahoneys Island that only contained native or non-invasive alien species (i.e., no $C$. varia), unlike on the southeast end of the island where $C$. varia was certainly the most conspicuous plant species, and there was almost no area where only native species were present. 

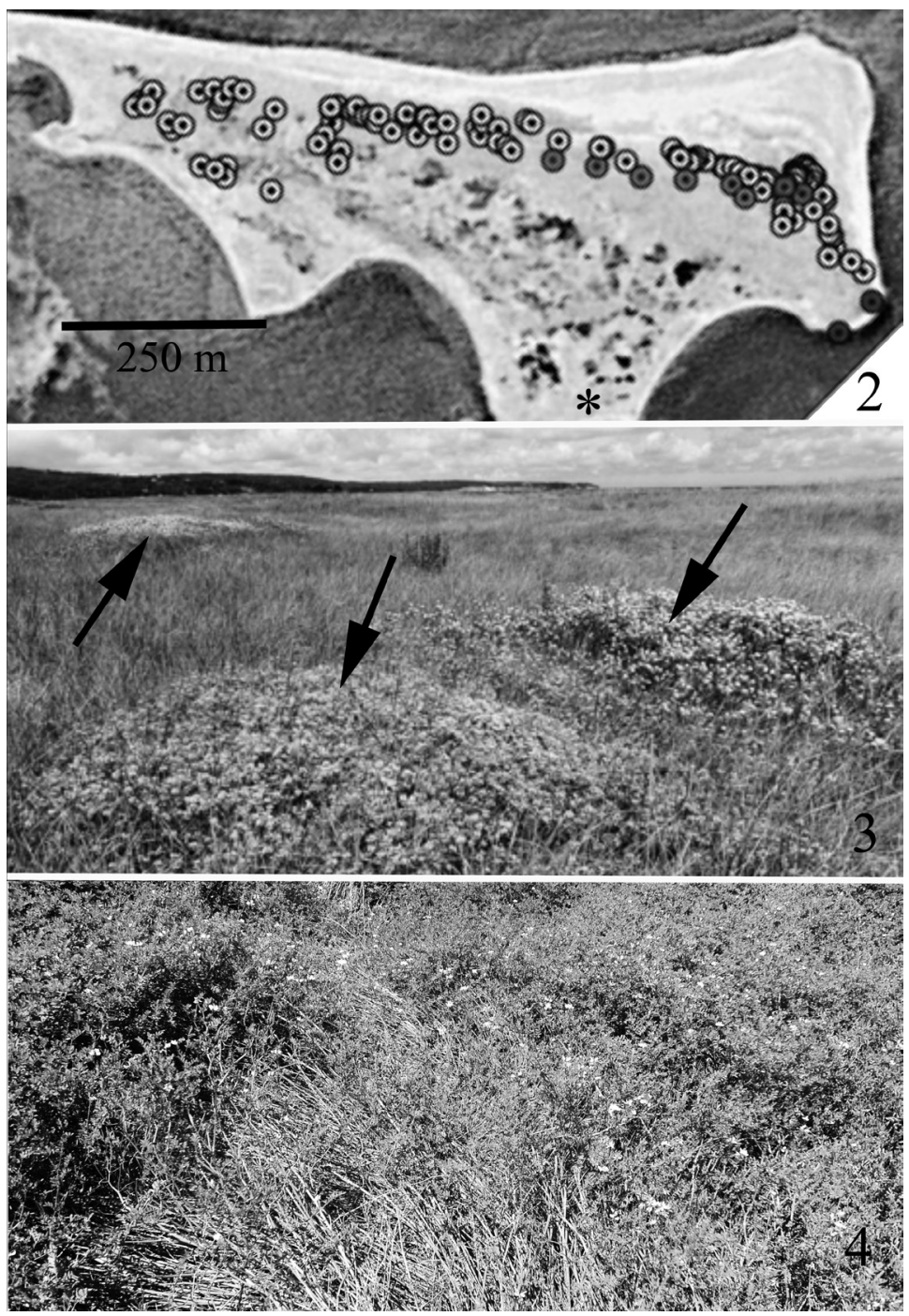

Fig 2 Mahoneys Beach with 125 colonies of Coronilla varia indicated (round markers) and outlier population associated with Rosa virginiana and copse of Populus tremuloides (asterisk). Scale bar $=250 \mathrm{~m}$.

Fig 3 Portion of Mahoneys Island dune dominated by Ammophila breviligulata showing three clumps (arrows) of dense Coronilla varia, each about 5 m diameter.

Fig 4 Portion of continuous sward of Coronilla varia with $100 \%$ cover showing dense aggregation of stiff, erect shoots; photograph shows about $5 \mathrm{~m}$ of width within a larger colony. 


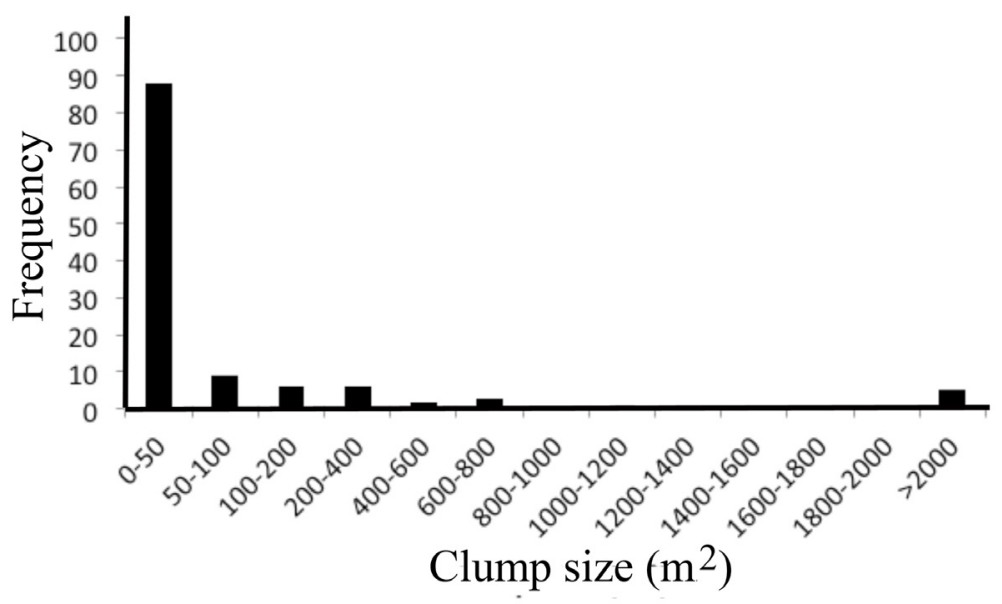

Fig 5 Size frequency distribution of Coronilla varia colonies on Mahoneys Island.

Coronilla varia achieved high biomass on Mahoneys Island, with biomass up to almost $700 \mathrm{~g} \mathrm{~m}^{2}$ dry mass. The relationship between cover and biomass was highly variable, even in colonies where there was $100 \%$ cover (Table 2 ). Plants of $C$. varia have very robust stems that allow them to be self-supporting, and over $70 \%$ of the above ground biomass is in stems with about $20 \%$ in leaves and the balance in flowers and fruits.

While our initial plan for the experimental evaluation of competitive interactions between Coronilla varia and four other species was not fully realized (due to loss of plots from dune retreat), it did allow us to evaluate changes in growth of $C$. varia in the presence of other species. In these $1 \times 1 \mathrm{~m}$ quadrats the cover of $C$. varia tended to increase when in the presence of the other species, i.e., from $13 \%$ to $32 \%$ during the four to six week experimental period (Tables 3 and 4). While none of these increases in growth were statistically significant at $\mathrm{p}<0.1$, when values for increase in cover for all four species were combined, $C$. varia showed a significant increase (Student's $t$ test, $\mathrm{p}$ $<0.1$ ). In the same quadrats, three of the four other species (all but L.japonicus) tended to decrease in cover; however, this decrease was only significant for A. breviligulata (Student's $t$ test, $\mathrm{p}<0.05$ ). When the cover values for the four other species were combined, these species collectively showed a significant decline in the same quadrats where the $C$. varia had increased (Student's $t$ test, $\mathrm{p}<0.05$ ). 
Table 2 Annual, above-ground production of Coronilla varia on Mahoneys Island in early September 2011 from different colonies with $100 \%$ cover $(n=10)$.

\begin{tabular}{lccccc}
\hline & $\begin{array}{c}\text { Erect shoots } \\
\mathbf{~ m}^{\mathbf{2}}\end{array}$ & $\begin{array}{c}\text { Total Dry } \\
\text { Mass } \\
\left(\mathbf{g ~ m}^{-2}\right)\end{array}$ & Stems (\%) & Leaves (\%) & $\begin{array}{c}\text { Flowers } \\
\text { and } \\
\text { fruits }(\%)\end{array}$ \\
\hline Minimum & 100 & 254 & 71.5 & 18.1 & 10.3 \\
Maximum & 292 & 679 & 73.5 & 23.8 & $\begin{array}{c}\text { (\%.6 } \\
\text { Mean } \pm \text { s.d. }\end{array}$ \\
\hline
\end{tabular}

Table 3 Percent cover and biomass of Coronilla varia in naturally occurring quadrats with Species 2, i.e., Ammophila,Toxicodendron, Myrica and Lathyrus (mean \pm s.d., $\mathbf{n = 6}$ ). Note Time 1 is mid June and Time 2 is late July 2011.

\begin{tabular}{ccc}
\hline Cover & Cover & Biomass \\
Time 1 $(\%)$ & Time 2 $(\%)$ & Time 2 $\left(\mathrm{g} \mathrm{m}^{-2}\right)$ \\
\hline
\end{tabular}

Coronilla with: Coronilla Species 2 Coronilla Species 2 Coronilla Species 2

\begin{tabular}{lrrrrrrr}
\hline Ammophila & $18.3 \pm 8.2$ & $65.0 \pm 21.7$ & $24.2 \pm 10.7$ & $36.7 \pm 10.3$ & $74 \pm 32$ & $217 \pm 75$ \\
Toxicodendron & $30.0 \pm 9.5$ & $40.0 \pm 20.7$ & $34.2 \pm 16.3$ & $29.2 \pm 7.4$ & $103 \pm 31$ & $217 \pm 75$ \\
Myrica & $12.5 \pm 7.6$ & $42.5 \pm 11.7$ & $20.8 \pm 13.2$ & $40.0 \pm 21.7$ & $62 \pm 49$ & $378 \pm 266$ \\
Lathyrus & $20.8 \pm 8.9$ & $16.7 \pm 9.9$ & $30.0 \pm 13.2$ & $21.7 \pm 10.3$ & $127 \pm 98$ & $31 \pm 14$ \\
\hline
\end{tabular}

Table 4 Increases in percent cover of Coronilla varia and other dune species after four weeks following removal in experimental plots with four different species. Note: control subplots were between and contiguous with clipped plots (Wilcoxon paired-sample test, $n=6$; NS, not significant at $p<0.1$ ).

\begin{tabular}{lcc}
\hline $\begin{array}{l}\text { Experiment } \\
\text { (Species 2) }\end{array}$ & $\begin{array}{c}\text { Response of Species 2 } \\
\text { after removal of Coronilla }\end{array}$ & $\begin{array}{c}\text { Response of Coronilla } \\
\text { after removal of Species 2 }\end{array}$ \\
\hline 1. Ammophila & $\mathrm{NS}$ & $\mathrm{NS}$ \\
2. Lathyrus & $\mathrm{p}<0.1$ & $\mathrm{p}<0.1$ \\
3. Myrica & $\mathrm{NS}$ & $\mathrm{NS}$ \\
4. Toxicodendron & $\mathrm{p}<0.1$ & $\mathrm{NS}$ \\
\hline
\end{tabular}

Average daily maximum irradiance within pure stands of Coronilla varia in mid-summer was $246 \pm 417 \mu \mathrm{mol}$ photons $\mathrm{m}^{-2} \mathrm{sec}^{-1}$. This was about $25 \%$ of the value from an adjacent non-vegetated area (935 \pm $1120 \mu$ mol photons $\left.\mathrm{m}^{-2} \mathrm{sec}^{-1}\right)$. The LI-COR irradiance measures taken from beneath stands of the various species on a single day showed species-specific variation in light transmission. In stands where $C$. varia had comparable cover to the other species, light penetration was similar for C. varia and Ammophila breviligulata (Table 1), reduced by one third under Lathyrus maritimus and Toxicodendron radicans, 


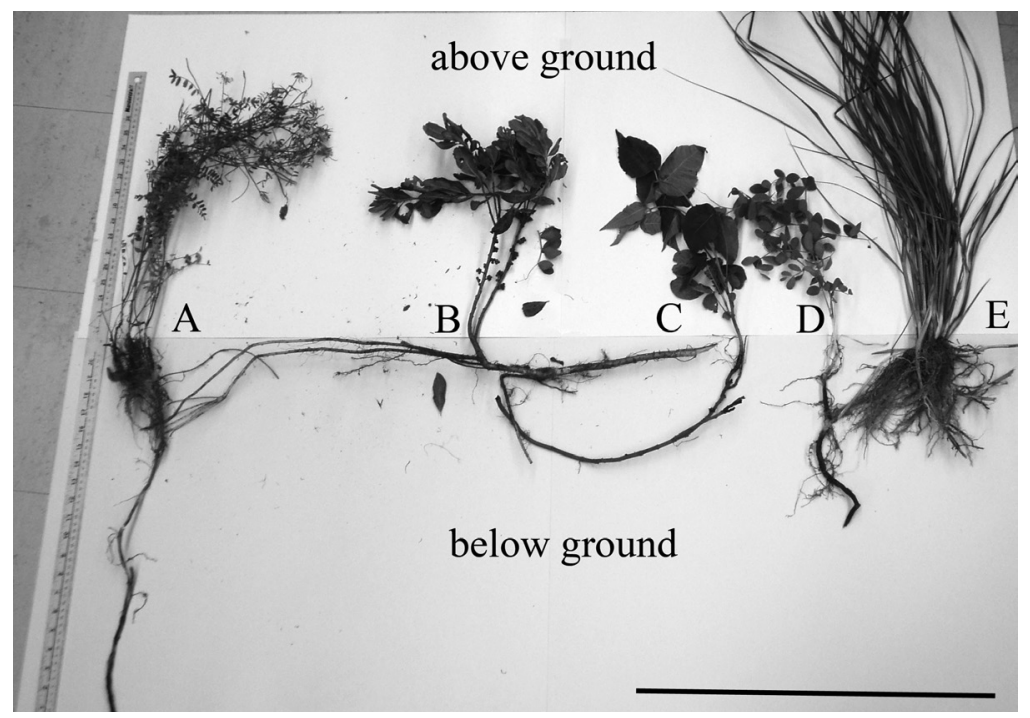

Fig 6 A comparison of root-rhizome vertical extents from A) Coronilla varia, B) Myrica pensylvanica, C) Toxicodendron radicans, D), Lathyrus maritimus and E) Ammophila breviligulata. Scale bar $=50 \mathrm{~cm}$.

and reduced by two thirds under canopies of Myrica pensylvanica. The latter is comparable to the irradiance under pure stands of $C$. varia.

When growing with four other sand dune species (Table 3), Coronilla varia showed a range in biomass from $62 \pm 49 \mathrm{~g} \mathrm{~m}^{-2}$ of dry mass when growing with Myrica pensylvanica, to $127 \pm 98 \mathrm{~g} \mathrm{~m}^{-2}$ when growing with Lathyrus maritimus. While these extremes are not statistically significantly different $(\mathrm{p}>0.1)$, they do illustrate a trend for $C$. varia to move into the spaces occupied by other species. Furthermore, this must be a transitory stage from successful colonization to virtual elimination of the other dune species. This is particularly evident in the large portions of Mahoneys Island previously occupied by Ammophila breviligulata and L. maritimus, where $C$. varia is the dominant (i.e. $>85 \%$ cover) and can achieve biomasses of over $400 \mathrm{~g} \mathrm{~m}^{-2}$ (Table 2).

Depth of root penetration varied among the different species on the sand dune (Fig 6). All of the native dune species (Myrica pensylvanica, Toxicodendron radicans, Lathyrus maritimus and Ammophila breviligulata) were mostly shallow rooted, with roots and rhizomes extending down to $20-30 \mathrm{~cm}$, with only a few thin roots penetrating deeper. In a monospecific clump of Coronilla varia, roots extended beyond the final pit depth of $100 \mathrm{~cm}$. 


\section{DISCUSSION}

Coronilla varia possesses characteristics of typical invasive species (Huenneke \& Thomson 1995, Maron \& Connors 1996, Symstad 2004; Walck et al.1999). It often out-competes native species and forms large single-species stands (Harper-Lore 1996, Tu 2003, USDA 2006). C. varia suppresses the growth of other plants, and experiments by Ang et al. $(1994,1995)$ showed that it could suppress even the invasive Canada thistle. Baskin et al. (2000) showed that the number of reproductive structures increased on the endangered plant Solidago shortii Torrey \& Gray when C. varia was removed from experimental plots, again demonstrating that $C$.varia suppresses the development of surrounding plants. This is consistent with our experimental plots where cover of Lathyrus maritimus and Toxicodendron radicans increased following removal of $C$. varia (Table 3). C. varia altered nutrient cycles in a sand prairie by increasing soil nitrogen availability (Symstad 2004). Altering nutrient cycles could encourage invasion by other invasive species that had previously been suppressed in nutrient poor and xeric environments (Symstad 2004), such as coastal sand dunes. C. varia can also regenerate from above-ground fragments, making it difficult to eradicate from an area once it is established (Losure et al. 2009).

As Coronilla varia interacts with and outcompetes other species, it proceeds from having sparse cover where there is little shading of the competitor species to where there is $100 \%$ cover and other species are excluded. In the quadrats where $C$. varia occurred with other species, it is intriguing that $C$. varia had the greatest light transmission (Table 1). From this we deduce that it is not competition for light that is allowing C.varia to dominate over the other species. Given that $C$.varia is becoming dominant in the vegetation zone normally occupied by Ammophila breviligulata and Lathyrus maritimus, it appears that $C$. varia is more tolerant of being shaded than either of the other species. In an agricultural ecosystem, $C$. varia survives and grows well under corn with shading in conditions ranging from $62-92 \%$ of full sunlight, although shade treatments reduced nodulation by up to $50 \%$ (Cardina \& Hartwig 1988). In an extensive review, Gucker (2009) lists seemingly contradictory reports of a wide range of shade tolerance by $C$. varia.

Losure et al. (2009) found no evidence that Coronilla varia builds up a large seed bank. This is to be expected given the low rates of sexual reproduction in clonal species (Erikkson 1989) such as C. varia. The root system can grow in sand, is multi-branched, and 
able to spread quickly by rhizomes (Tu 2003). Rhizomes can be up to $3 \mathrm{~m}$ long, and an individual plant is able to spread and cover $21-30$ $\mathrm{m}^{2}$ in four years (USDA 2006). Our observations on below-ground roots and rhizomes, show that $C$. varia penetrates much deeper than other dune species. Thus $C$. varia has access to moister substrata, and can 'harvest' nutrients over the entire soil profile, not just the upper 50 $\mathrm{cm}$ where the root-rhizomes systems of the other species are found. In addition, $C$. varia can tolerate a range of conditions: drought to heavy precipitation, and warm to cold temperatures (NBII and ISSG 2005), though it grows best with high levels of precipitation (Tipping 2001). Our observations on Mahoneys Beach show that $C$. varia is tolerant of high salinity and beach overwash. Elias \& Chadwick (1979) found that $C$. varia had low growth rates at establishment compared to other legume species. Regardless, the fact that $C$. varia easily regenerates from small vegetative fragments (Losure et al. 2009) may be the basis of its spread on Mahoneys Island and its subsequent spread to Dunns Beach.

Dune systems where invasive plant species have been present for a long time are less likely to return to the original vegetation, due to large seed banks of invasive species that are built up over time. Therefore, when the invasive species are removed, there is a higher reinvasion potential (Marchante et al.2008,2011). Although Coronilla varia has not been proven to build up a large seed bank, it does form monospecific stands that spread by robust rhizomes and perpetuate over time, and it can regenerate from above-ground fragments (Losure et al. 2009). Therefore, areas invaded by C. varia, in which this invasive plant has already colonized and lowered biodiversity, could become a self-sustaining system that is less resilient than normal, high biodiversity conditions.

Hill \& Blaney (2009) described Coronilla varia from the Maritime Provinces as a nitrogen-fixing, alien species being used for roadside stabilization in the region. However, they observed that no alien, herbaceous legumes appeared to be a threat to native ecosystems in this area. This observation can now be questioned by our findings.

Rosa rugosa Thunb. is a prime example of an invasive alien species that is well known throughout Europe, as well as in Nova Scotia (Bruun 2005, Weidema 2006, Isermann 2008, Hill et al. 2010). Hill et al. (2010) identified $R$. rugosa as invasive to Nova Scotia sand dunes in the southern Gulf of St. Lawrence where it occupied up to $8 \%$ of the dune area; it has not yet colonized any of the beach systems in St. Georges Bay. Roads, tracks, and house plantings can act as conduits 
for invasion of coastal sand dunes by this invasive shrub (Jørgensen and Kollmann 2009). Recently, R. rugosa was found to be invasive on Nova Scotia sand dunes, and its presence on the dunes was indeed associated with roads and nearby house plantings (Hill et al. 2010). The fact that C. varia is commonly used for roadside stabilization, and that prior to 2004 there was a track leading to the portion of Mahoneys Beach that is connected to the mainland, presents a possible mechanism for how C.varia was introduced to Mahoneys Beach. Pleasant Valley Nurseries (Henry Steghs, pers.comm.), in Antigonish, confirmed that C.varia has been sold and planted along roadsides and beachfront properties in an attempt to minimize coastal erosion near Mahoneys Beach. However, since $C$. varia seems to be more dominant and better established at the southeast end of the island, further from roads and housing, perhaps a marine dispersal method might be a better explanation, as for R. rugosa on Brier Island in the Bay of Fundy (Garbary, unpublished observations) and coastal Norway (Fremstad 1997). Animals could provide another vector, as seeds of $C$. varia can germinate from feces of white-tailed deer (Myers et al. 2004), and deer migrate over to the island portion of Mahoneys Beach for short periods.

The presence of nitrogen-fixing bacteria in root nodules allows the plant to grow in nutrient-deficient substrates, such as those found on sand dunes. Rodriguez-Echeverria et al. (2009) studied the invasive ability of Acacia longifolia (Andr.) Willd. They found that its associations with soil microorganisms and ability to nodulate profusely allowed it to fix nitrogen, and that this enhanced its invasive success. More recently, Rascher et al. (2012) demonstrated significant nitrogen inputs of A. longifolia in 3.5-fold the physical area occupied by the plant. The presence of native nitrogen-fixing species on Californian coastal prairies contributed to the success of invasive species because of the elevated nitrogen levels that they provided (Maron and Connors 1996). Thus, the presence of native nitrogen-fixing species (Myrica pensylvanica and Lathyrus maritimus in particular) may have aided in the establishment of Coronilla varia on Mahoneys Beach. The species was then able to persist due to its own nitrogen-fixing abilities and then outcompete other species based on its deeper roots that permit greater nutrient and water absorption over a larger soil depth.

Coronilla varia is well established on Mahoneys Beach. Approximately $9 \%$ of the island is now covered by 121 monospecific clumps of $C$. varia, with some being over $2000 \mathrm{~m}^{2}$ (the largest clump covering an impressive $9100 \mathrm{~m}^{2}$ ). These large monospecific colonies of 
C. varia confirm its invasive qualities as defined by Harper-Lore (1996) and USDA (2006). The large colonies and extensive rhizome system of $C$. varia suggest that it is using a guerrilla strategy (Harper 1977; Lovett-Doust \& Lovett-Doust 1982) to spread and increase the size of existing colonies. Herbaceous perennials, such as $C$. varia, with long distance clonal spreading (guerilla techniques), show the greatest relative increase in cover among moderately to highly disturbed habitats (Fahrig et al. 1994).C.varia also has the potential for prolific seeding (Tu 2003), but this does not occur in the first year of growth, and this can be severely limited by the abundance of major pollinators (e.g., honeybees, Gucker 2009). There was no conspicuous evidence of seedling establishment within stands of $C$. varia on Mahoneys Island. Mahoneys Beach can be considered a moderately to highly disturbed habitat because it is subject to storm surges (like the one in 2004 that breached the dune system and created the channel that now separates the island portion of the beach from the part connected to the mainland), and physical evidence of disturbance was observed (severe scarping on the seaward side of the dune).

Density and species richness of native species were compromised in areas invaded by C. varia. Pure colonies of Coronilla varia on Mahoneys Beach had shoot densities averaging 200 shoots $\mathrm{m}^{-2}$ (Table 2) and excluded native species. Similarly Burkitt \& Wootton (2011) found increasing density of the invasive plant Carex kobomugi Ohwi (a coastal dune sedge) increased the negative effects on native species. The exclusion of native species could be detrimental to sand dune ecology in the long term. Ammophila breviligulata and the nitrogen-fixers, Myrica pensylvanica and Lathyrus maritimus, are three of the native species that were examined in this study, and they are important for sand trapping and providing nitrogen in low nutrient soils, respectively.

Although it seems logical to associate high disturbance levels on sand dunes with invasion potential, the correlation between the two is unclear (Hill et al.2010), especially on a relatively undisturbed system such as Mahoneys Beach. It is also possible that $C$. varia may prove beneficial to sand dunes by moderating erosion from sea level rise that is having major impacts on sand beaches in the southern Gulf of St. Lawrence (Garbary et al. in preparation). This raises the question of whether species diversity and preservation of native species is more important than the possible benefits of $C$. varia for preventing erosion of sand dune systems. Whether $C$. varia is detrimental, or not, to long term sustainability of sand dune plant communities remains to be 
established; however, the obvious invasion and competitive strength of this species is a concern for the diversity and function of Mahoneys Beach and other sand dunes that have yet to be invaded.

Acknowledgements We thank Leah Beveridge for assistance in the field. M. Garbary and an anonymous referee provided valuable comments on an earlier version of the manuscript. This work was supported by grants from the Natural Sciences and Engineering Research Council of Canada to DJG.

\section{LITERATURE CITED}

Ang, B.N., Kok, L.T., Holtzman, G.I. \& Wolf, D.D. (1994). Competitive growth of Canada thistle, tall fescue, and crown vetch in the presence of a thistle defoliator, Cassida rubiginosa Muller (Coleoptera: Chrysomelidae). Biol. Contr. 4: 277-284.

Ang, B.N., Kok, L.T., Holtzman, G.I. \& Wolf, D.D. (1995). Canada thistle (Cirsium arvense (L.) Scop.) response to density of Cassida rubiginosa Muller (Coleoptera: Chrysomelidae) and plant competition. Biol. Contr. 5: 31-38.

Baskin, J.M., Walck, J.L., Baskin, C.C.\& Buchele, D.E. (2000) . Ecology and conservation biology of the endangered plant species Solidago shortii (Asteraceae). Native Plants J. 1: 35-41.

Beveridge, L.F. (2012). An assessment of the vegetation and integrity of the sand dunes of western Cape Breton Island, Nova Scotia. BSc Honours Thesis, St. Francis Xavier University, Antigonish, NS.

Bruun, H.H. (2005). Biological flora of the British Isles. Rosa rugosa Thunb. ex. Murray. J. Ecol. 93: 441-470.

Burkitt, J. \& Wootton, L. (2011). Effects of disturbance and age of invasion on the sand sedge, Carex kobomugi, on native dune populations in New Jersey's coastal dunes. J. Coast. Res. 27: 182-193.

Callaway, R.M.\& Aschehoug,E.T. (2000). Invasive plants versus their new and old neighbors: a mechanism for exotic invasion. Science 290: 521-523.

Cardina, J. \& Hartwig, N. L. (1988). Atrazine, Bifenox and shade effects on Crown vetch (Coronilla varia) nodulation and nodule activity. Weed Sci. 36: 535-539.

Elias, C.O. \& Chadwick, M.J. (1979). Growth characteristics of grass and legume cultivars and their potential for land reclamation. J. Appl. Ecol. 16: 537-544.

Erikkson, O. (1989). Seedling dynamics and life histories in clonal plants. Oikos, 55: 231-238.

Fahrig, L., Coffin, D.P., Lauenroth, W.K. \& Shugart, H.H. (1994). The advantage of long distance clonal spreading in highly disturbed habitats. Evol. Ecol. 8: 172-187. 
Fremstad,E.(1997). Alien plants in Norway. Japanese Rose-Rosa rugosa. Blyttia 55: 115-121. [in Norwegian].

Gucker, C.L. (2009). Coronilla varia. In: Fire effects information system, [Online].U.S. Department of Agriculture, Forest Service, Rocky Mountain Research Station, Fire Sciences Laboratory (Producer). Available: http:// www.fs.fed.us/database/feis/[2013, April 21].

Hales, W.J. (1992). Sand dunes of Nova Scotia. MSc Thesis, McMaster University, Hamilton, ON.

Harper, J.L. (1977). Population biology of plants. Academic Press, New York.

Harper-Lore, B. (1996). Coronilla varia. In Invasive plants: weeds of the global garden. Edited by Randall, J.M., and Marinelli, J. Brooklyn Botanic Garden. Brooklyn. p. 74.

Hill, N.M. \& Blaney, C.S. (2009). Exotic and invasive vascular plants of the Atlantic Maritime Ecozone. In: McAlpine, D.F. and Smith, I.M. (eds.), Assessment of Species Diversity in the Atlantic Maritime Ecozone. NRC Research Press, Ottawa, Canada. pp. 215-232.

Hill, N., Beveridge, L., Flynn, A. \& Garbary, D.J. (2010). Rosa rugosa as an invader of coastal sand dunes of Cape Breton Island and mainland of Nova Scotia. Can. Field Nat. 124: 151-158.

Huenneke, L.F. \& Thomson, J.K. (1995). Potential interference between a threatened endemic thistle and an invasive nonnative plant. Conserv. Biol. 9: 416-425.

Isermann, M. (2008). Expansion of Rosa rugosa and Hippophaërhamnoides in coastal grey dunes: effects at different spatial scales. Flora 203: 273-280.

Jørgensen, R.H. \& Kollmann, J. (2009). Invasion of coastal dunes by the alien shrub Rosa rugosa is associated with roads, tracks and houses. Flora 204: 289-297.

Lake, J.C. \& Leishman, M.R. (2004). Invasion success of exotic plants in natural ecosystems: the role of disturbance, plant attributes and freedom from herbivores. Biol. Conserv. 117: 215-226.

Losure, D.A., Moloney, K.A. \& Wilsey, B.J. (2009). Modes of crown vetch invasion and persistence. Am. Midl. Nat. 161: 232-242.

Lovett-Doust, L. \& Lovett-Doust, J. (1982). The battle strategies of plants. New Scientist 95 (1313): 81-84.

Madigan, M.T., Martinko, J.M., Stahl, D. \& Clark, D.P. (2010). Brock Biology of Microorganisms, $13^{\text {th }}$ edition. Benjamin Cummings, Boston.

Marchante, L., Freitas, H. \& Hoffmann, J.H. (2011). The potential role of seed banks in the recovery of dune ecosystems after removal of invasive plant species. Appl. Veg. Sci. 14: 107-119.

Marchante, L., Kjøller, A., Struwe, S. \& Freitas, H. (2008). Short- and long-term impacts of Acacia longifolia invasion on the belowground processes of a Mediterranean coastal dune ecosystem. Appl. Soil Ecol. 40: 210-217.

Maron, J.L. \& Connors, P.G. (1996). A native nitrogen-fixing shrub facilitates weed invasion. Oecologia, 105: 302-312. 
McClay, A. \& Faechner, T.R. (2008). Invasive alien plants in Canada - Summary Report. In: Brownell, B., Castro, K. and Gallant, B. (eds.) [online]. Available from http://epe.lac-bac.gc.ca/100/206/301/cfiaacia/2011-09-21/www.inspection.gc.ca/english/plaveg/invenv/techrpt/ summrese.shtml [accessed April 2013].

Myers, J.A., Velland, M., Gardescu, S. \& Marks, P.L. (2004). Seed dispersal by white-tailed deer: implications for long-distance dispersal, invasion, and migration of plants in eastern North America. Oecologia 139: 35-44.

National Biological Information Infrastructure (NBII) and Invasive Species Specialist Group (ISSG) (2005). Coronilla varia (herb). In: Hartwig N.L. (ed.), Global Invasive Species Database [online]. Available from http://www.issg.org/database/species/ecology.asp? si=276[accessed April 2013].

NatureServe. (2011). Coronilla varia - L.: Distribution [online]. Available from http://www.natureserve.org/explorer/servlet/Nature Serve? searchName $=$ Coronilla\%20varia [accessed March 2012].

Pyšek, P., Richardson, D.M., Rejmanek, M., Webster, G.L., Williamson, M. \& Kirschner, J. (2004). Alien plants in checklists and floras: towards better communication between taxonomists and ecologists. Taxon 53: 131-143.

Rascher, K.G., Hellmann, C., Máguas, C. \& Werner, C. (2012). Community scale ${ }^{15} \mathrm{~N}$ isoscapes: tracing the spatial impact of an exotic $\mathrm{N}_{2}$-fixing invader. Ecol. Letters 15: 484-491.

Rejmanek, M. (2011). Invasiveness. In: Simberloff, D. and Rejmanek, M. (eds.), Encyclopedia of Biological Invasions. University of California Press, CA. pp. 379-384.

Rodriguez-Echeverria, S., Crisótomo J. A., Nabais, C. \& Freitas, H. (2009). Belowground mutualists and the invasive ability of Acacia longifolia in coastal dunes of Portugal. Biol. Invasions 11: 651-661.

Roland, A.E. (1998). Roland's Flora of Nova Scotia, $3^{\text {rd }}$ edition. Nimbus Publishing Ltd. and Nova Scotia Museum, Halifax, Nova Scotia. 1297 pp.

Roland, A.E. \&d Smith, E.C. (1969). The flora of Nova Scotia. Nova Scotia Museum, Halifax, Nova Scotia. 746 pp.

Symstad, A.J. (2004). Secondary invasion following the reduction of Coronilla varia (Crown vetch) in sand prairie. Am. Midl. Nat. 152:183-189.

Thompson, M. (1997). Invasive plants of Canada: an introduction. Canadian Botanical Conservation Network [online].http://archive.rbg.ca/cbcn/ en/projects/invasives/invadel html [accessed April 2013].

Tipping, P.W. (2001). Canada thistle (Cirsium arvense) control with hexazinone in crown vetch (Coronilla varia). Weed Technol. 15: 559-563.

Tu, M. (2003). The Nature Conservancy's Wildland Invasive Species Team, and Dept. of Vegetable Crops and Weed Sciences. Element Stewardship Abstract for Coronilla varia L. University of California, Davis, CA.

USDA Forest Service. (2006). Weed of the Week: Crown Vetch Coronilla varia L. [online]. Available from http://www.na.fs.fed.us/fhp/invasive_ plants/weeds/crown-vetch.pdf [accessed April 2013]. 
USDA Natural Resources Conservation Service.(2009). Securigera varia (L.) Lassen.http://plants.usda.gov/java/profile? symbol=SEVA4 [accessed April 21, 2013]

Utting, D.J. \& Gallacher, A.F. (2009). Coastal environments and erosion in southwest St. Georges Bay, Antigonish County. Mineral Resources Branch, Nova Scotia Department of Natural Resources. Report ME 2009001. P. 139-149. (available on line at http://www.gov.ns.ca/natr/meb/data/ pubs/09re01/09re01_20Utting.pdf)

Walck, J.L., Baskin, J.M. \& Baskin, C.C. (1999). Effects of competition from introduced plants on establishment, survival and reproduction of the rare plant Solidago shortii (Asteraceae). Biol. Conserv. 88: 213-219.

Weidema, I. (2006). NOBANIS. Invasive Alien Species Fact Sheet: Rosa rugosa. [online]. Available from www.nobanis.org [accessed April 2013].

Zar, J.H. (1999). Biostatistical Analysis, $4^{\text {th }}$ ed. Prentice Hall, Upper Saddle River, New Jersey. 663 pages + appendices. 